\title{
Smuggling in the Dodecanese under the Italian Administration
}

F.M. Espinoza, University of Trento \& G. Papanicolaou, Teesside University ${ }^{1}$

\begin{abstract}
This chapter draws on archival and other source to offer an exploration of the sociopolitical context of smuggling and of official responses towards it during the period of the Italian rule of the Dodecanese between 1912 and the beginning of the Second World War. We develop an analysis of how local socioeconomic conditions and the wider geopolitical context underpinned the development of the response of the Italian administration. We argue that the gradual transition from a largely tolerant to a stricter approach towards smuggling generally relates to changes in the sociopolitical context of the Italian rule and particularly the relations between Italy and the Ottoman Empire after the Italo-Turkish war of 1912. Our account contributes to arguments against the dominant current tendency to approach illicit economic activity and 'organised crime' as devoid of historical context and separate from the 'upperworld' realities.
\end{abstract}

Keywords: Italy, Dodecanese, Italian Islands of the Aegean, smuggling, political economy, illegal markets.

\section{Introduction}

This chapter offers an exploration of the socio-political context of smuggling in the Dodecanese in the era of the Italian occupation and then Administration (1912-1943), particularly between 1924, when the region formally came under Italian rule, and the beginning of the Second World War. ${ }^{2}$

Beyond a contribution to the developing field of the historical study of the region during this

\footnotetext{
1 Filippo.espinoza@unitn.it, g.papanicolaou@tees.ac.uk

2 Work for this project is supported by a British Academy Small Research Grant (SG132031). We would also like to thank Ioannis Papageorgiou, the Rhodes Centre for Historical and Social Research (Rhodes Project) SCE, and Irene Toliou, Director of the Greek General State Archives of the Dodecanese, for their generous support of our work. We would also like to extend our gratitude to the participants of the Rhodes Project SCE workshop 'Aspects of fascist expansionism in the Aegean: Rhodes at the centrestage', Rhodes, 28 June 2014, for the lasting inspiration and stimulating comments they have offered us on that wonderful day.
} 
particular period, a closer look at the policies of the Italian colonial regime towards smuggling raises a series of interesting questions for the study of the political economy of illegal markets. It is often the case today that the alarmism of official discourses on organised crime leaves little margin for a sober consideration of the complex relationship between illicit economic activity and the official policies and efforts to suppress that activity. In this light, illegal markets, clandestine flows of goods and services and the forms of social organisation that sustain them are typically approached and understood as a grave and unmitigated threat to social and political order and the state's fiscal and political interests more particularly. Our examination of the Dodecanese under the Italians, however, offers compelling reasons to question the wisdom of drawing such an absolute line of demarcation between the (under)world of clandestine economies and the (upper)world of state interests and policies. Despite its ambitious and serious intention to establish a colonial regime that would act as a showcase of the achievements of the metropolis, the Italian Administration of the Dodecanese not only approached the smuggling activities of local populations as a relative threat to the social order it sought to establish; it also understood illicit economic activity as a tool in the service of its vital and long-term interests in the region.

Our chapter, in tune with other contributions to this volume, is primarily aimed as a rejoinder to contemporary debates on organised crime, advancing the idea that what is called 'organised crime' can be fully understood as an issue only within a political economy framework (Block \& Chambliss, 1981). In other words, illegal markets and the forms of social organisation that sustain them cannot be narrowly approached as a technical matter of crime prevention and suppression, but rather as social practices and strategies, which are rooted in historically given conditions, reflect particular economic, social and political interests, and may thus be symbiotic with or antagonistic to other social practices and strategies, particularly those promulgated by the state.

We offer here only a selective overview of our investigation of smuggling in the Dodecanese during the Italian rule, an effort which has made extensive use of archival and documentary sources and is itself inscribed within a wider programme of research on the history of the Italian Administration. Given our aim, we only touch upon questions concerning the extent to which the Italian Administration can be viewed as a typical colonial pacification project or the extent to which it deviates from other Italian colonial projects; nor do we delve on the significance of the Administration's relations with metropolitan Italy's fascist regime, except in so far as they are of import for situating the former's approach to smuggling. Rather we focus on the Administration's policies towards smuggling as responses to the economic and political problems and opportunities this activity presented, particularly the first six years of the Italian rule during which illegal markets 
were for all practical purposes openly tolerated by the authorities.

The remainder of this chapter is organised in three parts: the first part situates historically the phenomenon of smuggling in the region of the Dodecanese, whereas the second part documents the Administration's policy and practice towards the prevalent and persistent reality of smuggling in the Dodecanesian archipelago. The concluding discussion codifies the results of our inquiry and offers a reflection on its implications for contemporary debates on organised crime.

\section{Situating smuggling in the economic life of late 19th-early 20th century Dodecanese}

The chapter in Dodecanesian history, which we examine, begins with the landing in Rhodes of an Italian force under general Giovanni Ameglio in early May 1912. The occupation of the Dodecanese was completed within the same month and was only intended as secondary, temporary pressure front in the Italo-Turkish war of 1911, the main theatre of which had been Libya. The occupation was, however, to last throughout the 1910s, well beyond the conclusion of the Tripolitanian war with the Treaty of Ouchy in October 1912, until 1924, when the region was formally annexed to Italy following the Treaty of Lausanne.

The Italians thus came to succeed the Ottoman Empire in the possession of a region whose history was punctuated by geography, demography and politics. The Dodecanese or Southern Sporades, are spread over an area of two hundred and seventy thousand square kilometres between Crete and Anatolia. Patmos is the northernmost island, the southernmost being Kastellorizo. The other islands are Agathonisi, Lipsos, Kalymnos, Nisyros, Tilos, Halki, Symi, Kasos, Karpathos, Rhodes and Astypalea. The largest islands are Rhodes (1,412 km2), Kos (282 km2) and Karpathos (277 km2), with no other island being larger than one hundred square kilometres. Dominated by mountains, the Dodecanesian landscape is inhospitable and does not lend itself well to farming (Desio, 1924). Located at the south-eastern Aegean Sea, close to the most arid area of the Mediterranean, the islands receive no precipitation for half of the year (May to October), while during the winter they are exposed to strong winds and violent storms.

Historically, the scarcity of water and arable land has represented an insurmountable obstacle to agricultural development. During the Ottoman times, limited, subsistence agriculture was the rule across the region, even though on the two largest islands, Rhodes and Kos, which have the $85 \%$ of arable land in the region, did develop an agricultural economy depending heavily on fresh fruit and vegetables that could be traded in other parts of the Eastern Mediterranean. Other common crops, mostly destined for local consumption, were cereals and also olives, grapes and tobacco. Yet even in Rhodes, farming was limited to the northern coast, the rest of the island being mountainous (Arca 
Petrucci, 2010). The archipelago had lived under a constant threat of famine and emigration was endemic in older times. Even well into the 19th century, developments in chemistry and agricultural engineering had not been introduced to the region perpetuating the extreme backwardness of the systems already in place. As a result the yield was always uncertain (Vannutelli, 1909). Rural populations lived in extreme poverty, characterised by low consumption, surplus labor, land scarcity, backwardness and traditionalism. Leprosy, malaria and typhoid fever threatened the lives of people, living conditions were unhealthy, and nutrition was poor and deficient in protein.

The position of the archipelago, found at the intersection of the main nautical routes between Europe, Egypt and the Levant, and also the fact that most of the smaller islands offer good landing approaches, encouraged the development of activities related to the sea. Fishing and sponge trading had been practiced since the ancient times, but, overall, the potential for seafaring had remained limited until the 19th century. As pirates and privateers prevailed throughout the modern age in the Aegean sea, the fear of raids and pillaging had forced people to concentrate only in fortified towns, like Rhodes, Kos and Astypalea, or on the heights. Thus only Rhodes and Kos had been major seaports until the 19th century. The Town of Rhodes, in particular, had been an important commercial and strategic node in the region, featuring two small ports, Mandraki (Port of the Galleys) and Port of Commerce (Porto Colonna), as well as a natural bay, Akandia, which, during the first two centuries of Ottoman rule, were more than sufficient to cater for nautical and seafaring needs.

With the development of steam navigation and the opening of the Suez Canal in the second half of the 19th century, the region gained a renewed economic significance and islands specialising in fishing and sponge trading (Kalymnos, Symi, Halki and Kastellorizo), were able to tap into this development. During this period, the demand for sponges grew significantly at an international scale, due to this material's domestic and industrial uses (Mastrolia, 2003). The Dodecanesian merchants could rely on emigrant villagers and a distribution network, which extended across the principal European ports. Even "the most barren islands of the archipelago" (Stefenini \& Desio, 1928) benefited from these developments and the blossoming of this industry boosted businesses more generally. As a result, the economic expansion made possible noticeable improvements in the living standard of the population as well as a significant increase in population numbers. General Ameglio commented in 1913 that

the population currently is double of what was a century ago; and [...] the municipalities[,] with the money collected for various taxes or by voluntary fundraising among the natives dwelling abroad[,] were able to equip their islands with free schools, public pharmacies, 
and even construct with their own means public works of some significance, such as the docks of Kalymnos, Symi and Nisyros (Ameglio, 1913)

The development of economic activity across the region in the last few decades of the Ottoman rule also benefited from the relative decline of the ports of Rhodes, which were in poor condition and poorly maintained, inadequate to accommodate modern ships. These latter were forced to anchor in open waters thus making embarking and disembarking extremely difficult during the winter. Between November and April maritime trade was carried out only occasionally, and maritime and commercial activities were scarce. So the development of Rhodes itself was relatively curtailed, with industry limited to a few small factories, fairly insignificant from an economic perspective (Jaja, 1913). According to Ameglio, the decline in commercial traffic could also be attributed to the development of the port of Izmir, which, before the Italian occupation "catered almost completely for the commercial needs of the population."

The overall pattern of economic activity was also reflected in the demography of the region. An analysis of data relating to population density by Alexis Franghiadis (2009) showed that in the late Ottoman period, smaller islands such as Kastellorizzo, Symi and Kalymnos had a population density exceeding 200 inhabitants per square kilometre. In contrast, the most peripheral as well as the main islands, including Rhodes, which was the most populated one and hosted the main urban centre of the region, the capital Town of Rhodes, did not exceed a population density of 50 inhabitants per square $\mathrm{km}$. The distribution of both population and growth, encouraged the appearance of ancillary businesses and industries, such as small factories, coastal shipping, shipbuilding, and tobacco. These activities helped generate alternative income in the periods during which activities related to the sponge fishing ceased, and created employment opportunities for those who could not work in the fisheries sector. The overall sense of growth in the region was unmistakable:

In the off-season the women made cigarettes from imported tobacco, many of which were smuggled into Greece. With their wealth, settlers from Calymnos bought farms on the mainland, and sold European goods in Budrum and up the gulfs. There were similar settlers from Cos. [...] Like Calymnos also, Symi had farms and small settlements on the mainland and on the peninsula of Cnidus to the north, where there are both cattle pastures and plantations of olives and almonds. [...] there was a flourishing yard for building sponge-trading boats and small vessels, and for prompt and skilful repairs [...] In modern times [Cos] established a lucrative trade in fresh fruit and vegetables with Egypt, carried till recently in its own spacious and speedy sailing vessels (Myres, 1941, p. 147). 
Yet the fates of the archipelago depended on 19th century economic developments as much as they depended on the political regime to which the islands were subject. Following his conquest of the region in 1522, Suleiman the Magnificent granted the Dodecanese a regime of privileges consisting in ample administrative and fiscal autonomy, which was largely retained by the Ottoman authorities until the tanzimat reform period of the mid-19th century (Inalcik \& Quataert, 1997). That the Dodecanese have been often called 'privileged islands' originates precisely from the introduction of this particular regime. The islands, with the exception of Rhodes and Kos, enjoyed complete selfgovernment, consisting in authorities elected by the local communities on a yearly basis (known as demogeronties). The demogerontia exercised complete administrative authority over loval affairs, including the collection of taxes locally, part of which funded government expenses and public works. The tax obligation of each island to the Ottoman authorities only consisted in a lump tribute paid in two instalments yearly, while the Ottoman authorities retained a modicum of representation in the form of the local sumpasha, an official, who was nevertheless prohibited from "any intermeddling with the affairs of the Dodecanesians" (Zervos, 1919, p. 53). Given the composition of the population, these local institutions, particularly in the late Ottoman period, were effectively controlled by the landlords inland and the urban bourgeoisie of Greek origin (Doumanis, 1997, p. 24).

The global change of the 19th century, beyond entwining the Ottoman economy in the general boost of international trade, also entailed an increased European influence on Ottoman institutions, leading to major restructuring undertaken during the tanzimat reform period between 1839 and the end of the first constitutional era in 1878 (Inalcik \& Quataert, 1997). In the process, the Dodecanesian islands were reorganised administratively into a singular province (vilayet) and were thus brought under the uniform administrative framework of the Empire introduced at that time. The Ottoman authorities, however, were unsuccessful in abolishing the privileges of the islands as their attempts on several occasions were met with considerable local resistance (Doumanis, 1997, p. 29). The political conditions that had been conducive to those islands' growth remained largely intact until at least 1881, when the Empire ceded partial control of the collection of a series of taxes and duties to the Ottoman Public Debt Administration, an organisation that superintended the servicing of Ottoman public debt to European creditors. The coming of the Ottoman Public Debt Administration involved the introduction of a series of monopolies and therefore the collection of the corresponding taxes and duties on tobacco, salt, alcohol, and even the license fee for fishing, that was also required for sponge fishing. Local resistance to these developments proved increasingly futile, and, ultimately, the implementation of radical reform programme of the Young 
Turks brought all privileges to an end in July 1909 and also involved the collection of taxes and duties by the Ottoman authorities without exception or exemption (Alhadeff, 1927).

We are now able to situate the vibrancy of smuggling within the ebb and flow of Dodecanesian life on the eve of the Italian occupation. To be sure, the geopolitical changes in the Aegean had given scope to a lucrative smuggling activity directed towards the newly established Greek state earlier in the 19th century. As mentioned previously, the exemptions enjoyed by the privileged islands had encouraged the growth of a local tobacco industry that drew raw material from local sources or from the Anatolian mainland and, often clandestinely, advanced the final product abroad. The legacy of this activity proved lasting:

A minor industry of Kalymnos is the cutting of tobacco for cigarettes, which employs some hundreds of the women. The tobacco is grown in Kos, Samos or further afield, and comes simply to be cut and shipped elsewhere. The industry is now quite an open one; but it seems to have originated in days when a good deal of smuggling went on between the islands under Turkey and those included in the Greek kingdom (Myres, 1920, p. 337)

Following the establishment of the Ottoman Public Debt Administration and the introduction of a monopoly on tobacco, the scope of this business became considerably larger, as the clandestine flows could now target markets in the Turkish mainland as well as the non-privileged islands . In fact, because the OPDA was controlled by The Ottoman Empire's european creditors, the Ottoman authorities themselves had little interest in suppressing the activity. At the same time, the eventual ebb of the sponge trade encouraged the islanders to exploit more actively the advantages of the local ship-building industry and to turn more actively to the transportation of goods between Egypt and the southern coast of Anatolia. Islands like Kastellorizo ultimately abandoned sponge trading altogether (Doumanis, 1997, p. 18). In this context, the clandestine tobacco industry grew to an extent that smuggling was practiced virtually in plain daylight: in 1922, in Kalymnos alone there were 30 tobacco workshops, each one employing between ten and 400 people and contributing to an overall annual production of $60 \mathrm{~m}$ cigarettes (Guidoni, 1922). As one of the military commanders of the Dodecanese Vittorio Elia commented later on, "under the Ottoman regime, smuggling constituted the only and true profession of Calymnos, Symi and Chalki, that specialised in this industry" (Elia, 1918b).

The Italian occupation beginning in the turbulent 1910s was thus to be confronted with a genuine riddle-not merely with a problem of economic decline and clandestinisation, but rather with a puzzle rooted deeply in questions of local government and international politics. To this we 
turn in the next section.

\section{Smuggling and the Administration of 'Italy's Aegean Islands'}

Given the region's objective strategic position in the eastern Mediterranean, the Italian occupation of the Dodecanese appears to have been preponderantly a move to exert additional pressure on the Ottomans during the Libyan war. Whether in the Spring of 1912 the Italians had a genuine intention to annex the islands is a moot point. From an economic perspective, the Dodecanese's value was highly questionable and, at any rate, the composition of its preponderantly ethnic Greek population did not lend itself well to the Italian colonialist imaginary (Labanca, 2002, p. 180). To be sure, the same desire for colonial expansion that underpinned the Libyan war animated the Italian elites' ambitions towards the eastern Mediterranean. Italy had been present in developments in the Ottoman Empire firstly as early as 1881 as a party in the Ottoman Public Debt Administration and then later on by joining the supervision of the agreement between Turkey and Greece on the issue of the Cretan State (Bosworth, 1996, p. 52). At the time of the Libyan War, the islands could at best be viewed vaguely as a foothold towards the establishment of an Italian zone of influence in Asia Minor, an idea that enjoyed some currency among Italian business and political circles at the time. In the context of the negotiations to end the Libyan war, however, the Italians appeared reluctant to hold on to the islands with their priority being to gain full control of Libya, or advance their foreign policy goals in Albania (Doumanis, 1997, p. 34; Bosworth, 1970).

Yet as the war in Libya turned out to be the prelude to the Balkan wars of 1912-13, and, eventually, to the Great War, so the international situation surrounding Italy's occupation of the Dodecanese changed. At the end of the Balkan wars Italy was still in possession of the islands, having cunningly used them as a bargaining tool in the period that intervened between the Treaty of Ouchy and the Treaty of Bucharest in July 1913. The redrawing of the borders in the Balkan peninsula and the acceleration of the Ottoman Empire's disintegration had amplified the scope for Italian gains, and, in fact, with the 1915 Treaty of London Italy was promised full possession of the islands and a sphere of influence in Asia Minor in exchange for entering the war on the side of the Entente (Bosworth, 1970). The 'temporary' occupation of the Dodecanese was to last for almost a decade until the Treaty of Lausanne in 1923 formally awarded the region to Italy, but with the latter's sight firmly set on Anatolia in anticipation of a further disintegration of the newly established Republic of Turkey, the islands came to be understood as an important lever for the pursuit of Italy's unsettled ambitions on the Turkish mainland.

This international context is important because it provides, in our view, some important clues to 
understanding the approach of the Italian Administration of the Dodecanese towards illicit economic activity in the region. Bold as this suggestion may be, an approach recognising this impact of this context on the Administration's grip on illicit markets and economic activity would result in a modification of conventional periodisations of Italy's possession of the Dodecanese. A conventional periodisation based on the general 'domestic' Italian policy in the Dodecanese roughly recognises three general periods a) the 'temporary' occupation between 1912-1924 b) the period of Mario Lago's 'modernising' governorship 1924-1936 and c) the properly 'fascist' administration under Cesare De Vecchi after 1936 (Doumanis, 1997). Yet when the international political context of the Possedimento is taken into account as a factor underpinning Italian policy, it is possible to insert an additional period under Mario Lago lasting between 1924 and 1928, at which point Italo-turkish relations were normalised following the signing of the Neutrality and Reconciliation treaty by the two countries (Barlas, 2004).

The significance of this context firstly becomes noticeable in the immediate consequences of the Italian occupation and the outbreak of the First World War on the region's economic life. Italy's entry in the war on the side of the Entente and the Ottoman Empire's siding with the Central Powers prolonged the devastating effects of the Italo-turkish war on the islands' economic life. As Turkey severed communications with the islands, the latter were deprived of goods, such as meat, poultry, vegetable and fresh fruit, which were sourced from the Anatolian Coast and on which they depended (Myres, 1920, p. 337). Sponge fishing and trading, which had been a significant source of income of the region, continued to decline. After the revolution of the Young Turks in 1909, the introduction of direct taxation and conscription directed the activity to sponge-grounds in the Libyan sea and depleted the workforce employed in the trade. In the 1910s the establishment of the Italian monopoly on sponge fishing in Libya excluded Dodecanesians from those waters; later on between 1915 and 1919, the activity was altogether banned and many sponge-fishers had to migrate (Myres, 1941). More generally speaking, the severance of the region's relations and exchange with Asia Minor meant that the former's position on what just a few years earlier had been the busiest route between Egypt and Greece suddenly became a lot less significant for commerce.

It appears therefore that developments on the international plane had an objective impact on the economic life of the region independently of developments on the domestic setting of the region, that is, of the policies of the Italian occupation. These latter, beyond the containment of Greek irredentism that the Italian occupation itself ignited in the first place, were cautious and largely respectful of the islands' status quo in matters of local government and taxation (Pignataro, 2011). Although the Italians did progressively erect an administrative bureaucracy to superintend 
local affairs, wartime Dodecanese existed, after all, in a sovereignty limbo, and the Italians continued to view the islands as a stepping stone towards further penetration in Anatolia. In fact, the deteriorating economic conditions confronted the Italians with a problem of a different order, which regarded the very sustenance of the Dodecanesian population. The islands were never self-sufficient in basic supplies, including food. With the major local routes from Asia Minor, the Black Sea and Greece cut-off or severely restricted, acute shortages began to be felt and as early as the first months of 1915 the Italian military command was required to organise supply lines from metropolitan Italy and, increasingly during the later stages of the war, via the port of Alexandria (Elia, 1918a). Nevertheless, the shortages were never resolved. As "famine made itself cruelly felt" and foodstuffs and other basic goods such as lamp oil became scarce and excessively expensive, the Italians resorted to a system of rationing which, beyond adding to the general discontent, also "encouraged smuggling" (Tsirpanlis, 1998).

Whether the Dodecanese recovered subsequently from the immense economic and social damage it suffered during the Great War is highly uncertain. The restoration of the islands supply and trade lines with the Anatolian coast, following the Armistice of Mudros in 1918 and the partitioning of the Ottoman Empire with the Treaty of Sèvres, proved temporary. The new Republic of Turkey raised again barriers to trade akin to the wartime ones, this time against a Dodecanese that was brought formally under Italian sovereignty, following the 1922 Treaty of Lausanne. This was a situation that persisted throughout the 1920. Reflecting on the situation retrospectively in 1928 , the journalist Vittorio Gayda commented that

commerce of the archipelago suddenly ceased for four important reasons essentially: (a) the prohibitive tariffs of the new Turkey, (b) the concentration of customs services and all their operations in Smyrna and Adalia, with the suppression of all the intermediary services like that of Scalanova [Kușadası, Aydin], which served more directly the economic contact between the islands and the mainland, (c) the suspension of foreign transport services and therefore of Italian ones to the turkish coast, and (d) an insurmountable suspicion of the strictest kind against all attempts at peaceful Italian commercial expansion (Gayda, 1928, p. 148)

Gayda was unambiguous about the inevitable consequences for the local economic life:

Under the pressure of these four negative elements, but, above all, of the increasing distrust and resistance of the Turkish authorities, the commerce of the Dodecanese has been driven back from the Turkish coast, and, therefore, it has been cut off from its vital 
base. There is no more commerce except contraband. Defying storms and the darkness of the night in order to survive, Greek and Turkish sailors lease their boats and sails towards the coast, furtively loading and unloading goods with the complicity of the indigenous population (Gayda, 1928, p. 149).

Yet from a political perspective there was no doubt that the 1920 s were a new era in Dodecanesian history. Coinciding with the rise to power of Mussolini in Italy, the annexation of the islands opened up the prospect of a more intensive and extensive programme of embedding Italian sovereignty in them, and, ultimately, of building a showcase and an 'ubi consistam' of Italian power in the Levant (Lago, 1924). To this end, the Possedimento was brought under a regime that differentiated it from both the Italian metropolis and the Italian colonies in Africa, is so far as the royal decree of 28 August 1924, which established it, awarded extensive powers and autonomy to the figure of the Governor of the Italian Islands of the Aegean (Pignataro, 2013). The appointed governor, Mario Lago, a career diplomat, who possessed strong connections within the Italian bourgeoisie, thus enjoyed substantive autonomy vis-à-vis the Italian government in Rome and was answerable directly to the Italian Ministry of Foreign Affairs. He was also granted almost complete control over the Dodecanese, with full legislative, executive and fiscal powers, and even powers extending into the domain of the judicial function: in a sense, the exercise of Italian sovereignty was delegated to the office of the governor (Alhadeff, 1927, p. 123). This political autonomy was so wide and ad personam to such an extent that Lago's successor in 1936 remarked that "the possedimento was ruled by [such] patriarchal systems as if it were a private company more or less" (De Vecchi, 1936, p. 243)

Equipped with such autonomy and powers the regime undertook an extensive 'modernising' effort. This on one hand involved projects underpinned by the colonialist logic of pacification centered on the maximisation of economic exploitation, and, on the other, projects animated by the political and cultural visions of ascending fascism. A programme of major public works resulted in the development of modern water supply, road, telegraph and telephone networks, new public buildings, restoration of monuments, archaeological excavations; later on, there were plans to develop the islands as a destination for turism (Martinoli \& Perotti, 1999). Importantly, the Italians undertook to reorganise or develop a series of local industries, such as tobacco, mineral extraction, forestries and local crops by establishing companies such as TEMI or CAIR. The effort also extended to establishing control of inter-island transport, at the exclusion of local operators. Particularly in agriculture and forestry the regime's modernising effort consisted in the development of new 'model' settlements, supported by especially established scientific agencies to support development 
and to increase production in these these sectors (Pignataro, 2013; Doumanis, 1997).

There is no doubt that the regime's colonialist intentions were serious and ambitious, all the more because the Dodecanese provided Italy with an opportunity to develop a colony of a 'new' type, in which the predominantly white local populations would be assimilated into fascism's social vision (Labanca, 2002, p. 180). In reality, however, the colony's financial position remained precarious, since it never ceased to depend generous subsidies from the central government in Rome. It is also a moot point whether it developed at any point an economic significance beyond the trade flows to and from the Italian mainland, and the Possedimento's overall balance of trade throughout the Italian era remained "greatly passive" (Crivellari, 1935). According to Doumanis, 'the Rassegna Economica Delle Colonie, a contemporary Italian journal with up-to-date economic statistics, showed consistent negative trade balance figures. Between 1928 and 1932, the tonnage of imports outweighed exports ten-fold' (1997, p. 47). In the 1920s, tension with Turkey continued to define the region's economic situation. The latter not only forced the Italians to abandon their more ambitious plans, such as the development of Rhodes into a free port and thus an influential commercial node in the eastern Mediterranean. It also brought them to accept the realities of local economic life, which was squeezed through the clashing rocks of Italian colonialist programmes and severance from its natural interchange with the Anatolian Coast.

In this context, smuggling not only continued to flourish, but it came to be seen by the authorities as a necessity. Reporting to Rome as early as September 1924, governor Mario Lago remarked:

$[T]$ he reopening of the east coast is a matter of life or death for the commerce of Rhodes [...] The local effects of this crisis are intuitive. A large part of the Dodecanesian population that used to live on the Anatolian trade, currently suffers from the darkest poverty. Rather, in order to survive, it throws itself into riskier smuggling. Naturally, even though they know it is not the Italian regime's fault that such disaster has befallen them, the Dodecanesians do not hold a high opinion of our authority. Which helps create a widespread mood, if not of hostility, at least of distrust, very harmful to the order of our regime. Smuggling becomes every day more organised in almost regular form with the collaboration of the Turks from the coast, who suffer from the uneconomical situation created by the Turkish government as much as our subjects. This government does not encourage smuggling, but neither does it apply itself to repressing it. Is it ever possible that the government of the islands offer to be the gendarme on Turkey's behalf and force these people to starve to death? I have many times stated that I consider the leaner regular trade preferable to the 
richest smuggling. I was thus always sincerely prepared to adopt measures of close collaboration between the authorities of the islands and the authorities of the coast aimed at eliminating all customs fraud. But to do so, it is necessary that the government of Ankara decide to revoke the measures taken in hatred of Italy and of the Dodecanesians and to allow free play to economic laws (Lago, 1924).

It then appears that, from the viewpoint of the islands' authorities, the prevalence of smuggling and the under-enforcement of the customs regime went beyond the obvious difficulties posed by the extensive coastline or the lack of sufficient number of law enforcement officers, either of the Carabinieri or the Guardia di Finanza (Cecini, 2014). It was also not a problem related to the complexity or the weaknesses of the customs regime itself: in fact, the relative leniency of that legislative regime, which until the 1930s punished customs offences with fines that would often be minimal or conditional ones, arguably provided an additional tool to the regime's tolerant stance to an activity that presented a 'natural' solution to a predominantly political problem of government. The strictly fiscal interests of the regime tied to customs enforcement were thus seen as subordinate to questions of maintaining order and upholding the regime's legitimacy among the local population. These in turn were instrumental to the equally political purpose of sustaining Italy's foothold towards further economic penetration into Anatolia, a region which was still viewed as geopolitically unsettled and thus as a long-term goal for Italy's expansionist ambitions throughout the 1920s.

The archival sources from Rhodes often suggest that law enforcement officials were quite aware of both such political exigencies and of the regime's stance towards smuggling, allowing a two-fold interpretation of that situation. On one hand, officials would often support the petitions or appeals for leniency submitted by those convicted of smuggling offences, precisely on grounds of poverty or inability to pay the fine. On the other hand, the case may have been that no direct damage was inflicted on the regime's fiscal and wider economic interests, to the extent that smugglers would smuggle to Greece and Turkey goods produced and legitimately acquired in the Italian territory. For example, reporting in 1936 on individuals involved in smuggling activities, the commander of the Carabinieri noted that

in the past [the first individual] has exercised effectively and notoriously, on a large scale, the smuggling of alcohol and other goods at the expense of Greece and Turkey, an activity which was seen favourably by the [Italian] government of the time, also because it did not do any harm to our treasury, as he had always declared the merchandise which bought in order to smuggle it subsequently. ... [the other individual] managed to attain a solid 
financial position, particularly with profits he made by exercising, as is well known to us, the smuggling of cigarette paper in our favour and at the expense of Greece and Turkey (Grassini, 1937).

This second idea lends itself well to an understanding of why the toleration of smuggling by the Italian authorities continued to some extent into the 1930s. The normalisation of Italo-Turkish relations with the conclusion of the Neutrality and Reconciliation treaty in 1928 also coincided with the consolidation and modernisation of Italian customs legislation. The latter also brought about changes in the framework of sanctions against smuggling, doubling the amount of statutory fines and upgrading it to a criminal offence punished with a custodial sentence of one to five years. It also introduced aggravating circumstances such as armed smuggling, conspiracy to commit smuggling by three or more persons, or smuggling with the use of counterfeit documents or bribery and corruption of officials. Attempt, complicity and the reception of smuggled goods also became punishable offences by the Gubernatorial Decree 121 of 3 June 1930 (Istituto Coloniale Fascista, 1932, pp. 690-691). So the change in the circumstances of the international political environment in the direction Lago was advocating in 1924 also brought about changes aimed at curbing smuggling. However, the regime in the Dodecanese still left leeway to take individual circumstances of the locals into account by means of pardons and amnesties. Additionally, smuggling still represented an opportunity for local economic interests to retain a channel of access to markets on the Turkish coast. By that time these interests had been integrated to some extent into the Italian economic modernisation programme and the production circuits that programme had engendered-for example, the individual mentioned in the Carabinieri report above was among the members of the local business elite in Patmos and in turn had relations with prominent commercial actors in Rhodes. At any rate, whether the Italian toleration to smuggling also involved a strategy to coopt those local economic and social elites, would be an interesting and plausible research hypothesis.

The end of Mario Lago's governorship and his replacement by the ardent fascist Cesare de Vecchi in 1936 brought about a thorough change in the regime's policy towards local conditions. In the intervening period between his arrival and the outbreak of the Second World War, De Vecchi implemented policies which were directly in tune to the metropolitan regime's approaches and were directly aiming towards full Italianisation and political domination of the Dodecanesian populationinevitably, policies coloured by intensive repression of political dissidence. De Vecchi's 'domestic' policies in the Dodecanese and the subsequent crackdown on smuggling should be understood, again, in a two-fold perspective. Firstly, from an economic viewpoint, on the eve of the Second World War, about 70 per cent of the region's produce, went to Italy, while about 75 per cent of the 
imports came from Italy, including the large quantities of construction materials used in the public works (Myres, 1941, p. 154). Therefore, the Administration had a greater interest in strictly enforcing customs legislation. Secondly, this development must be viewed also in the context of international developments and the opening of a new war theatre in east Africa with the Italian invasion in Ethiopia in 1935. From that point forward and into the Second World War, smugglers were also seen as a potential military threat due to their intimate knowledge of the waters and of the coast. In 1935, for example, the Italian consulate in Piraeus, Greece, reported back to the Ministry of Foreign Affairs that

an officer of passport controls of the English consulate of Athens turned to known smugglers of Piraeus in order to find out whether they would be prepared, eventually, to take up the responsibility of transporting clandestinely weapons and war material, various supplies, and to carry out acts of espionage in the Dodecanese [...] The above mentioned smugglers have replied that more useful than themselves are, for the Dodecanese, the dodecanesian smugglers resident in Piraeus and suburbs, who know perfectly all the islands of the Aegean (Ministero degli Affari Esteri, 1935).

\section{Conclusion}

Our case study of dodecanesian smuggling during the era of the Italian Possedimento shows how the regime's enforcement approach varied over time, for reasons well beyond any immediate considerations of law and order or crime suppression. Rather, the formulation of that approach had been contingent on a double confrontation. As aspiring colonialists, the Italians were firstly confronted with the reality of local conditions that were firmly rooted in the region's economic, social and political history; as fledging imperialists, secondly, they had to defend their newly acquired territorial gains from the shifts and turns of the very same world power games that brought them to the region in the first place.

Our analysis understands the policy of the regime towards smuggling as 'tolerance' of smuggling. While the official line of prohibition and sanctioning of smuggling had been naturally prescribed by the law, the archival and other historical sources offer compelling indications that the Italian authorities understood smuggling as a political necessity as much as the local populations understood smuggling as a necessity of economic life. This latter vitally depended on supply and trade routes extending beyond the porous borders of the region. The severing of those routes meant life on the verge of extreme poverty and famine. It is not the case, of course, that particular 
individuals did not take up the obvious opportunities to exploit and make fortunes out of their fellow islanders' plight. Some of them undoubtedly did, but the these trajectories, much more than personal aberrations (Hobbs, 2013), were contingent on the wider historical conditions and socioeconomic structure.

Our point is that the newly established authorities of these barren islands were very much part of that structure: for them, smuggling was not an unequivocal threat, but rather it presented both a threat and an opportunity: a threat, in so far as the activity of the local population in the vibrant clandestine markets of the region inflicted risks and losses to the regime's fiscal health; yet an opportunity nevertheless, in as much as these clandestine markets acted as a cushion of sorts, absorbing social tensions that posed a threat to the political stability of the newly established and geopolitically precarious Italian rule on the region. Our political economy analytical perspective would also interrogate the use of this opportunity as going beyond a mere strategy of political pacification of an abstract local population. Our material raises valid and interesting questions regarding the significance of illegal markets and smuggling in the articulation of local elites and the Italian regime into new networks of economic and social power in the region.

While we recognise the limitations that are inherent in a work in progress and the gravity of the tasks lying ahead, our account as it stands is already, at a bare minimum, a cautionary tale. Drawing from an unlikely historical context in the study of illegal markets, we can join those voices (e.g., Hobbs, 1998; van Duyne, 1996) that argue against the dominant current tendency to approach illicit economic activity and 'organised crime' as devoid of historical context and separate from power relations that traverse social and political hierarchy in its entirety.

\section{References}

Alhadeff, V. (1927). L'ordinamento giuridico di Rodi e delle altre isole Italiane dell'Egeo. Milano: Istituto Editoriale Scientifico.

Ameglio, G. (1913). Contributo monografico per lo studio politico ed economico dell'isola di Rodi. Rhodes: Tipo-litografia del Comando della 6a Divisione Speciale.

Arca Petrucci, M. (Ed.). (2010). Atlante geostorico di Rodi. Territorialità, attori, pratiche e rappresentazioni (1912-1947). Rome: Gangemi.

Barlas, D. (2004). Friends or foes? Diplomatic relations between Italy and Turkey, 1923-36. International Journal of Middle East Studies, 36, 231-252.

Block, A. A., \& Chambliss, W. J. (1981). Organising crime. New York: Elsevier.

Bosworth, R. J. B. (1970). Britain and Italy's acquisition of the Dodecanes, 1912-1915. The Historical Journal, 13(4), 683-705.

Bosworth, R. J. B. (1996). Italy and the end of the Ottoman Empire. In M. Kent (Ed.), The Great Powers and the end of the Ottoman Empire (2nd ed., pp. 51-72). London: Frank Cass.

Cecini, G. (2014). La Guardia di Finanza nelle isole italiane dell'egeo 1912-1945. Rome: Gangemi 
Editore.

Crivellari, Q. (1935, 20 April). Commercio dei cambi. [Report of Crivellari to the Ministry of Foreign Affairs, Telespresso n. 16780, dated 20 April 1935]. Direzione Generale Affari Commerciali, Egeo 1930-1935 (category 28, file 'Questioni finanziarie'). Diplomatic Historical Archive of the Ministry of Foreign Affairs: Rome.

De Vecchi, C. (1936). Report of the second Italian governor, De Vecchi, to the Italian Foreign Minister, Ciano, on the situation in the Dodecanes on the assumption of his duties. In L. Divani \& P. Constantopoulou (Eds.), The Dodecanese: the long road to union with Greece. Dimplomatic documents from the Historical Archives of the Ministry of Foreign Affairs (pp. 231-256). Athens: Kastaniotis Editions.

Desio, A. (1924). La potenzialità agricola delle isole del Dodecaneso e $i$ suoi rapporti con la constituzione geologica. Florence: Istituto Agricolo Coloniale Italiano.

Doumanis, N. (1997). Myth and memory in the mediterranean: remembering fascism's empire. Basingstoke: MacMillan.

Elia, V. (1918a, 26 June). Rapporto a MAE. [Report to the Ministry of Foreign Affairs, 26 June 1918, signed Elia]. Archivio di Gabinetto 1915-1918 (box 56, file 4). Diplomatic Historical Archive of the Ministry of Foreign Affairs: Rome.

Elia, V. (1918b, 6 October). Rapporto a MAE. [Report to the Ministry of Foreign Affairs, 6 October 1918, signed Elia]. Archivio di Gabinetto 1915-1918 (box 56, file 4). Diplomatic Historical Archive of the Ministry of Foreign Affairs: Rome.

Franghiadis, A. (2009). La politica ecnomica del fascismo nel Dodecaneso: il periodo del governatore Mario Lago (1923-1936). In M. Peri (Ed.), La politica culturale del fascismo nel Dodecaneso: atti del convegno - Padova 16-17 november 2007 (pp. 51-61). Padova: Esedra.

Gayda, V. (1928). L'economia del Dodecaneso. L'Oltremare, 4, 146-149.

Grassini, G. (1937, 16 March). Situazione del comune di Patmo. [Report on the situation of the community of Patmos, from Grassini to De Vecchi, 18 March 1937]. Affari Politici 1931-1945, Dodecaneso-Egeo (box 13, file 7). Diplomatic Historical Archive of the Ministry of Foreign Affairs: Rome.

Guidoni, U. (1922, II problema doganale di Rodi. [Attachment to a report of Count De Bosdari, governor of Rhodes]. Affari politici 1919-1930 (box 985, file 2410). Diplomatic Historical Archive of the Ministry of Foreign Affairs: Rome.

Hobbs, D. (1998). Going down the glocal: the local context of organised crime. The Howard Journal, 37(4), 407-422.

Hobbs, D. (2013). Lush life: constructing organised crime in the UK. Oxford: Oxford University Press.

Inalcik, H., \& Quataert, D. (Eds.). (1997). An economic and social history of the Ottoman Empire, volume 2: 1600-1914. Cambridge: Cambridge University Press.

Istituto Coloniale Fascista. (1932). Annuario delle colonie Italiane e paesi vicini. Rome: Castaldi.

Jaja, G. (1913). L'isola di Rodi. Rome: Società Goegrafica Italiana.

Labanca, N. (2002). Oltremare: storia dell'espansione coloniale italiana. Bologna: Il mulino.

Lago, M. (1924, 7 September). Commercio del porto di Rodi. [Report to the Ministry of Foreign Affairs, telespresso n. 8227, 7 September 1924, signed Lago]. Direzione Generale Affari Commerciali, Egeo 1924-1926 (category 4, fiile 2). Diplomatic Historical Archive of the Ministry of Foreign Affairs: Rome.

Martinoli, S., \& Perotti, E. (1999). Architettura coloniale italiana nel Dodecaneso. Torino: Fondazione Giovanni Agnelli.

Mastrolia, F. A. (2003). La pesca delle spugne nel Mediterraneo del secolo XIX. Napoli: Edizioni Scientifiche Italiane.

Ministero degli Affari Esteri. (1935, 23 October). Contrabbando di armi e spionaggio per il Dodecaneso. [Transcript of a communication from the Italian consulate of Piraeus to the 
Ministry of Foreign Affairs, Telespresso n 237891, 23 October 1935].

Myres, J. L. (1920). The Dodecanese. The Geographical Journal, 56(5), 329-347.

Myres, J. L. (1941). The islands of the Aegean. The Geographical Journal, 97(3), 137-156.

Pignataro, L. (2011). I: Il Dodecaneso italiano 1912-1947: i lineamenti giuridici l'occupazione iniziale: 1912-1922. Chieti: Edizioni Solfanelli.

Pignataro, L. (2013). II: II Dodecaneso italiano 1912-1947: il governo di Mario Lago 1923-1947. Chieti: Solfanelli.

Stefenini, G., \& Desio, A. (1928). Le colonie, Rodi e le isole Italiane dell'Egeo. Torino: UTET.

Tsirpanlis, Z. (1998). Italokratia sta Dodecanisa. Rhodes: Office of the Medieval Town of Rhodes.

van Duyne, P. (1996). The phantom and threat of organised crime. Crime, Law and Social Change, 24, 341-377.

Vannutelli, L. (1909). L'isola di Rodi. Bolletino della Società Geografica Italiana, 46.

Zervos, S. (1919). The Dodecanese: the history of the Dodecanese through the ages, its services to mankind and its rights. London: A. Page. 